\title{
UPAYA MENINGKATKAN KEKUATAN LEMPARAN STANDING SHOOT DALAM PERMAINAN BOLA BASKET MELALUI LATIHAN PUSH UP
}

\author{
Agus Nurdiana \\ SMP Negeri 2 Susukan Lebak Kabupaten Cirebon, Indonesia \\ agusnurdiana78@gmail.com
}

\begin{abstract}
One form of physical and spiritual coaching is through sports activities, but each person has certain limitations both in terms of interests, talents as well as diverse economic abilities, this will certainly result in the types of sports choices that he will follow will also vary. In basketball, a player must have hand strength when going to a standing shoot throw. Therefore we need an exercise to increase the strength of the throw. Physical Education Learning Game basketball material for VIIID grade students of SMP Negeri 2 Susukan Lebak Cirebon Regency, some students have difficulties. Most students are still weak in standing shot shoots. The author tries to overcome the problems of students by doing push-up exercises in research activities. This research uses a class action research method. This research is located at SMP Negeri 2 Susukan Lebak Cirebon Regency with research subjects of Class VIII-D Students in 2019/2020 Academic Year as many as 23 students. The results showed the learning of basketball games with push up training techniques had a positive impact in improving student achievement in terms of standing shoot students which was marked by an increase in student learning completeness in each cycle, namely prasiklus (43.47\%), cycle I 69.59\%), cycle II (91.30\%).
\end{abstract}

Keywords: Power of throw, standing shoot, basketball, physical education.

\begin{abstract}
ABSTRAK
Salah satu bentuk pembinaan jasmani dan rohani adalah melalui bentuk kegiatan olahraga, namun setiap orang memiliki keterbatasan tertentu baik dari segi minat,bakat juga kemampuan ekonomi yang beragam, hal ini tentu akan berakibat jenis pilihan olaharaga yang diikutinya akan beragam pula. Dalam permainan bola basket, seorang pemain harus memiliki kekuatan tangan ketika akan melakukan lemparan standing shoot. Oleh karena itu diperlukan suatu latihan untuk meingkatkan kekuatan lemparan. Pembelajaran Penjas materi permainan bola basket pada siswa kelas VIIID SMP Negeri 2 Susukan Lebak Kabupaten Cirebon, beberapa siswa memiliki kesuliatan. Kebanyakan siswa masih lemah dalam melakukan lemparan standing shoot. Penulis mencoba mengatasi permasalahan siswa dengan melakukan latihan push up dalam kegiatan penelitian. Penelitian ini menggunakan metode penelitian tindakan kelas (Class action research). Penelitian ini bertempat di SMP Negeri 2 Susukan Lebak Kabupaten Cirebon dengan subyek penelitian Siswa Kelas VIII-D Tahun Pelajaran 2019/2020 sebanyak 23 siswa. Hasil penelitian menunjukkan pembelajaran permainan basket dengan teknik melatih push up memiliki dampak positif dalam meningkatkan prestasi belajar dalam hal standing shoot siswa yang ditandai dengan peningkatan ketuntasan belajar siswa dalam setiap siklus, yaitu prasiklus (43,47\%), siklus I 69,59\%), siklus II (91,30\%).

Kata Kunci: Kekuatan lemparan, standing shoot, permainan bola basket, pembelajaran penjas
\end{abstract}

Submitted December 3, 2019 | Revised December 7, 2019 | Accepted December 15, 2019

\section{Pendahuluan}

Olahraga merupakan salah satu aktivitas fisik yang tidak dapat dipisahkan dari hidup manusia. Olahraga merupakan faktor penting dalam upaya pemeliharaan kesehatan manusia. Menurut UNESCO, olahraga merupakan aktivitas fisik berupa permainan yang berisikan perjuangan melawan unsur-unsur alam, orang lain ataupun diri sendiri. Seiring pertumbuhan ilmu pengetahuan dan teknologi serta perubahan pola pikir, masyarakat Indonesia mulai menganggap bahwa olahraga merupakan kebutuhan yang harus mereka penuhi. Dewasa ini, masyarakat Indonesia mulai melakukan kegiatan olahraga, dari berniat hanya sebatas ikut-ikutan teman, hobi, sampai ada yang ingin menyalurkan bakatnya menjadi atlet berprestasi di cabang olahraga yang 
dikehendakinya. Banyak sekali cabang olahraga yang sekarang menjadi favorit masyarakat untuk dilakukan dan salah satunya adalah bola basket.

Olahraga yang sekarang menjadi favorit masyarakat untuk dilakukan dan salah satunya adalah bola basket. Olahraga permainan bola basket adalah sebuah permainan yang sederhana. Rahasia permainan bola basket yang baik adalah melakukan hal-hal sederhana dengan sebaik-baiknya. Bola basket merupakan jenis olahraga yang akhir-akhir ini begitu cepat perkembangannya dan banyak menarik perhatian dalam kehidupan manusia (Ahmadi, 2007: 2 ).

Permainan bola basket dapat dikatakan merupakan permainan yang sederhana, akan tetapi memiliki beberapa faktor yang menguntungkan. Permainan bola basket hanya membutuhkan biaya yang relatif murah, karena hanya membutuhkan sedikit sekali peralatan dan dapat dengan mudah dimainkan dengan fasilitas yang minim dan tersedia. Namun kenyataan dilapangan permainan bola basket kurang berkembang dikalangan sekolah, padahal permainan bola baskettidak memerlukan biaya yang besar dan sarana yang banyak.Oleh karena itu penulis ingin sekali menanamkan dan mengembangkan permainan bola basketkepada anak didik untuk mau melakukannya dan menyenangi permainan bola basket. Bola basket merupakan permainan yang dimainkan oleh dua regu, baik putra maupun putri yang masing-masing regu terdiri dari lima orang pemain (Muhajir, 2003: 32).

Permainan bola basket merupakan salah satu cabang olah raga permainan bola besar, namun tampaknya kurang berkembang baik di masyarakat luas maupun di lingkungan sekolah. Faktor pendukung dalam teknik permainan bola basket yang paling dominan adalah kecepatan membawa bola, daya ledak dan kekuatan, meskipun demikian faktor kelincahan dan kelenturanpun tidak kalah pentingnya, terutama dalam melakukan lemparan ke gawang dengan teknik yang baik dan tepat dapat menghasilkan goal yang baik.

Olahraga bola basket harus memerlukan teknik dasar yang baik agar bisa memberikan hasil yang baik dalam suatu pola permainan. Ada beberapa teknik dasar dalam perminan bola basket, yakni Dribling, Shotting, Passing teknik dasar itu harus bisa dikuasai oleh seorang atlet atau pemain bola basket (Pridani, 2017). Dalam permainan bola basket, shooting adalah lemparan yang sangat penting peranannya. Pemainan yang melakukan shooting dengan baik merupakan ancaman yang berbahaya bagi lawan-lawannya karena pemain dapat dengan mudah memasukkan bola ke ring lawan dan menghasilkan poin untuk tim (Rustanto, 2017).

Daya ledak atau power pada saat melakukan lemparan ke gawang sangat terfokus pada daya ledak atau power otot lengan dan bahu, daya ledak ini dapat dilatih dengan berbagai cara di antaranya adalah dengan latihan push up. Berkenaan dengan latihan push up penulis menerapkan latihan push up agar menghasilkan kekuatan melempar yang optimal. Untuk itu melakukan tembakan dalam permainan bola basket memerlukan gerakan yang kompleks meliputi gerakan tungkai, tubuh, lengan dan gerakan lompatan vertical keatas. Jauh dekatnya tembakan dipengaruhi oleh posisi pemain dari ring dan jangkauan lengan pemain sehingga apabila jarak tembakan semakin jauh maka pemain harus melakukan teknik shooting yang lebih kuat dan tepat. Untuk melaksanakan tembakan tersebut dibutuhkan adanya singkronisasi antara kaki, punggung, bahu, siku tembakan, kelentukan pergelangan dan jari tangan (Wissel, Hall, 2000: 47).

Agar kondisi fisik, taktik, mental, dan kerjasama tim mengalami peningkatan maka dibutuhkan suatu latihan. Latihan adalah proses yang sistematis dari berlatih atau bekerja, yang 
dilakukan secara berulang-ulang, dengan kian hari menambah jumlah latihannya atau bekerja Irianto (2002). Menurut Bompa (1994: 4) latihan adalah suatu upaya seseorang mempersiapkan dirinya untuk mencapai tujuan tertentu. Pada prinsipnya latihan merupakan suatu proses perubahan kearah yang lebih baik, yaitu untuk meningkatkan kualitas fisik, kemampuan fungsional peralatan tubuh, dan kualitas psikis anak latih. Dengan latihan secara teratur diharapkan menciptakan gerakan-gerakan yang mudah, energi yang dikeluarkan menjadi efisien serta mampu , mencapai prestasi maksimum. Menurut M. Sajoto (1988), unsur kondisi fisik diantaranya adalah: "1) kekuatan, 2) daya tahan, 3) daya ledak, 4) kecepatan, 5) daya lentur, 6) kelincahan, 7) koordinasi, 8) keseimbangan, 9) ketepatan, 10) reaksi”. Masing-masing unsur kondisi fisik tersebut memiliki pengaruh yang cukup besar terhadap teknik bermain bola basket, seperti kita ketahui bahwa teknik dasar dari permainan bola basket adalah terutama pada memasukan bola ke gawang. Dengan menguasai teknik dasar dalam suatu pertandingan dapat menentukan keberhasilan suatu tim untuk memenangkan pertandingan. Salah satu faktor yang paling penting adalah penguasaan melemparkan bola ke gawang yang baik.

Dalam hal ini pun kemampuan fisik merupakan hal yang tak kalah pentingnya yang harus dimiliki seorang atlit permainan bola basket untuk mencapai prestasi yang optimal. Dengan kondisi fisik yang prima, penampilan teknik yang sempurna akan mempengaruhi efisiensi gerak. Melakukan proses latihan push up yang berulang-ulang dapat memperkuat alat lengan dan bahu yang akhirnya akan mempengaruhi hasil lemparannya.

Push-up merupakan gerakan yang menggabungkan seluruh tubuh, meskipun gerakannya dilakukan oleh sendi pergelangan tangan, siku, dan bahu yang melibatkan anggota tubuh bagian atas dengan target utama otot pectoralis major, deltoid anterior, rhomboidus, trapezius, coracobrachialis, serratus anterior, bisep, dan trisep (Penney, 2014: 2). Sukadiyanto (2010: 92) latihan push-up merupakan jenis kontraksi isotonik yang meningkatkan ketegangan otot pada saat otot dalam keadaan memanjang dan memendek yang melibatkan gerak persendian anggota badan.

\section{Metode Penelitian}

Penelitian ini merupakan Penelitian Tindakan Kelas yang dilakukan secara kolaborasi. Penelitian Tindakan Kelas berdasarkan pendapat Sanjaya (2011: 26) adalah proses pengkajian masalah pembelajaran di dalam kelas melalui refleksi diri dalam upaya untuk memecahkan masalah tersebut dengan cara melakukan tindakan yang terencana dalam situasi nyata serta menganalisis setiap pengaruh dari perlakuan tersebut. Pendapat tersebut sesuai pendapat yang disampaikan oleh Kasbolah (2001: 15), bahwa Penelitian Tindakan Kelas merupakan penelitian tindakan dalam bidang pendidikan yang dilaksananakan dalam kawasan kelas dengan tujuan untuk memperbaiki dan atau meningkatkan kualitas pembelajaran.

Banyak model Penelitian Tindakan Kelas yang dapat diterapkan, tetapi dalam penelitian ini menggunakan model Kemmis dan McTaggart di mana dalam perencanaannya menggunakan siklus sistem spiral yang di dalamnya terdiri dari empat komponen, yaitu rencana, tindakan dan observasi serta refleksi (Sujati, 2000: 23).

Dari gambar 1 mengenai desain penelitian maka penelitian tindakan yang akan dilakukan dapat diuraikan sebagai berikut: 


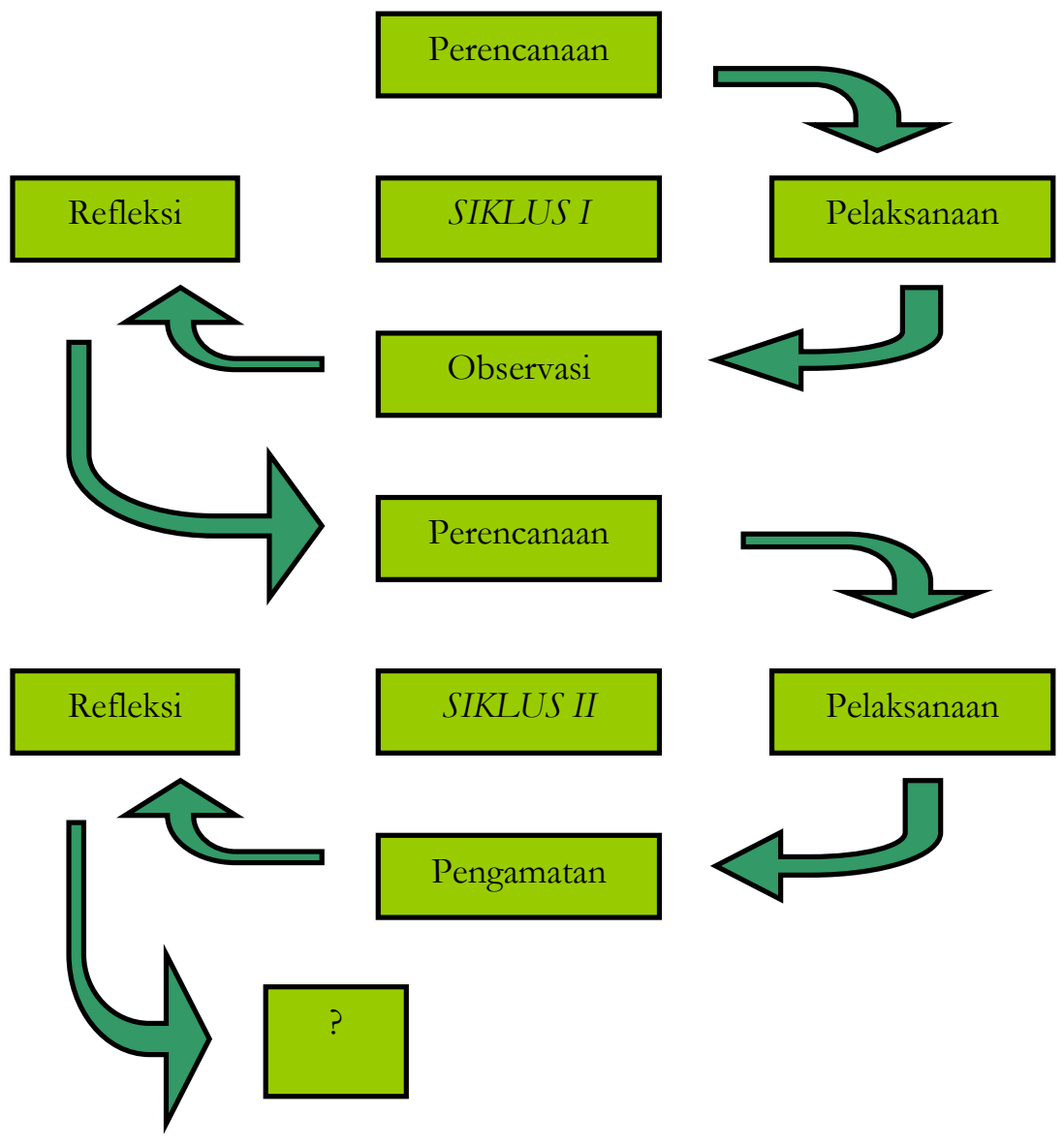

Gambar 1. Model kemmis dan Mc Taggart

\section{Perencanaan (Plan)}

Melakukan observasi terhadap situasi atau kemampuan motorik halus anak sebelum dilakukan tindakan, membuat Rencana Kegiatan Harian terlebih dahulu dengan berdiskusi bersama guru kelas (kolaborator), membuat media yang digunakan untuk kegiatan pembelajaran serta mempersiapkan peralatan yang dibutuhkan bersama kolaborator, mempersiapkan lembar observasi yang digunakan untuk mengambil data serta melakukan penilaian dan evaluasi, melakukan setting atau penataan ruang kelas yang mendukung kegiatan pembelajaran.

2. Pelaksanaan (Act) dan Observasi (Observe)

Pelaksanaan dilakukan sesuai dengan perencanaan yang telah dibuat guru kelas dengan peneliti. Pelaksanaan penelitan dilakukan secara fleksibel yaitu bisa berubah sesuai dengan situasi dan kondisi yang ada di lapangan. Guru kelas sebagai kolaborator melaksanakan tindakan yang sudah direncanakan sesuai RKH sedangkan peneliti mengamati proses pembelajaran yang berlangsung.

3. Refleksi (Reflect)

Refleksi dilakukan pada setiap akhir siklus untuk mengetahui apakah kegiatan mewarnai yang diberikan sudah sesuai harapan atau belum serta digunakan peneliti dan kolaborator dalam melakukan evaluasi tentang perlu tidaknya melakukan siklus selanjutnya. Selain itu, melalui refleksi 
dapat melakukan analisis data pada lembar observasi yang telah diisi oleh peneliti dan kolaborator serta melakukan penilaian untuk menyusun rencana perbaikan yang akan dilakukan (Arikunto, 2010).

Penelitian ini bertempat di SMP Negeri 2 Susukan Lebak Kabupaten Cirebon Tahun Pelajaran 2019/2020 dengan Subyek penelitian adalah siswa-siswi Kelas VIII-D Tahun Pelajaran 2019/2020 sebanyak 23 siswa.

Instrumen yang digunakan dalam penelitian ini terdiri dari perangkat pembelajaran, lembar observasi kegiatan belajar mengajar, Tes formatif. Perangkat pembelajaran yang digunakan berupa Silabus dan RPP, dan Lembar Kegiatan Siswa (LKS). Lembar observasi kegiatan belajar mengajar digunakan untuk mengumpulkan data pemberian tugas latihan push up serta untuk mengamati kemampuan guru dalam mengelola pembelajaran, dan mengamati aktivitas siswa selama proses pembelajaran. Tes formatif disusun berdasarkan tujuan pembelajaran yang akan dicapai. Tes formatif ini diberikan setiap akhir putaran. Bentuk soal yang diberikan adalah unjuk kerja

\section{Hasil dan Pembahasan}

1. Siklus 1

Tahap perencanaan pada siklus 1, penulis mempersiapkan perangkat pembelajaran yang terdiri dari rencana pelajaran 1, LKS 1, soal tes formatif 1, dan alat-alat pengajaran yang mendukung.

kegiatan belajar mengajar untuk siklus I dilaksanakan pada Hari Kamis tanggal 26 September 2019 di Kelas VIII D SMP Negeri 2 Susukan Lebak Tahun Pelajaran 2019/2020. dengan jumlah siswa 23 siswa.Dalam hal ini peneliti bertindak sebagai guru. Adapun proses belajar mengajar mengacu pada rencana pelajaran dengan memperhatikan revisi pada prasiklus, sehingga kesalahan atau kekurangan pada prasiklus tidak terulang lagi pada siklus I.Pengamatan (observasi) dilaksanakan bersamaan dengan pelaksanaan belajar mengajar.

Pada akhir proses belajar mengajar siswa diberi tes formatif II dengan tujuan untuk mengetahui tingkat keberhasilan siswa selama proses belajar mengajar yang telah dilakukan. Instrument yang digunakan adalah tes formatif II. Adapun data hasil penelitian pada siklus I adalah sebagai berikut

Tabel 1. Rekapitulasi Hasil Tes Formatif Siswa Siklus 1

\begin{tabular}{cll}
\hline No & Uraian & Hasil Siklus II \\
\hline 1 & Nilai rata-rata tes formatif & 69,56 \\
2 & Jumlah siswa yang tuntas belajar & 16 \\
3 & Persentase ketuntasan belajar & $69,56 \%$ \\
\hline
\end{tabular}

Dari tabel di atas diperoleh nilai rata-rata prestasi belajar siswa adalah 69,56 dan ketuntasan belajar mencapai 69,56\% atau ada 16 siswa dari 23 siswa sudah tuntas belajar. Hasil ini menunjukkan bahwa pada siklus I ini ketuntasan belajar secara klasikal telah mengalami peningkatan sedikit lebih baik dari prasiklus.Adanya peningkatan hasil belajar siswa ini karena setelah guru menginformasikan bahwa setiap akhir pelajaran akan selalu diadakan tes sehingga pada pertemuan berikutnya siswa lebih termotivasi untuk belajar. Selain itu siswa juga sudah mulai mengerti apa yang dimaksudkan dan diinginkan guru dengan menerapkan model pembelajaran 


\section{Siklus 2}

Tahap perencanaan pada siklus 2, penulis mempersiapkan perangkat pembelajaran yang terdiri dari rencana pelajaran 3, LKS 3, soal tes formatif 3, dan alat-alat pengajaran yang mendukung.

Pada siklus 2, Pelaksanaan kegiatan belajar mengajar untuk siklus II dilaksanakan pada Hari Kamis tanggal 3 Oktober 2019 di Kelas VIII D SMP Negeri 2 Susukan Lebak Tahun Pelajaran 2019/2020. dengan jumlah siswa 23 siswa. Dalam hal ini peneliti bertindak sebagai guru. Adapun proses belajar mengajar mengacu pada rencana pelajaran dengan memperhatikan revisi pada siklus II, sehingga kesalahan atau kekurangan pada siklus I tidak terulang lagi pada siklus II.Pengamatan(observasi) dilaksanakan bersamaan dengan pelaksanaan belajar mengajar.

Pada akhir proses belajar mengajar siswa diberi tes formatif III dengan tujuan untuk mengetahui tingkat keberhasilan siswa dalam proses belajar mengajar yang telah dilakukan. Instrumen yang digunakan adalah tes formatif III. Adapun data hasil peneitian pada siklus II adalah sebagai berikut

Tabel 1. Rekapitulasi Hasil Tes Formatif Siswa Siklus 1

\begin{tabular}{clc}
\hline No & Uraian & Hasil Siklus II \\
\hline 1 & Nilai rata-rata tes formatif & 77,39 \\
2 & Jumlah siswa yang tuntas belajar & 21 \\
3 & Persentase ketuntasan belajar & $91,30 \%$ \\
\hline
\end{tabular}

Berdasarkan tabel diatas diperoleh nilai rata-rata tes formatif sebesar 77,39 dan dari 23 siswa yang telah tuntas sebanyak 21 siswa mencapai ketuntasan belajar. Maka secara klasikal ketuntasan belajar yang telah tercapai sebesar 91,30\% (termasuk kategori tuntas).Hasil pada siklus II ini mengalami peningkatan lebih baik dari siklus I. Adanya peningkatan hasil belajar pada siklus II ini dipengaruhi oleh adanya peningkatan kemampuan guru dalam menerapkan model pembelajaransehingga siswa menjadi lebih terbiasa dengan pembelajaran seperti ini sehingga siswa lebih mudah dalam memahami materi yang telah diberikan. Pada siklus II ini ketuntasan secara klasikal telah tercapai, sehingga penelitian ini hanya sampai pada siklus II.

Berdasarkan hasil penelitian yang dilaksanakan pada siklus 1 dan 2, diperoleh beberapa temuan sebagai berikut:

a) Selama proses belajar mengajar guru telah melaksanakan semua pembelajaran dengan baik. Meskipun ada beberapa aspek yang belum sempurna, tetapi persentase pelaksanaannya untuk masing-masing aspek cukup besar.

b) Berdasarkan data hasil pengamatan diketahui bahwa siswa aktif selama proses belajar berlangsung.

c) Kekurangan pada siklus-siklus sebelumnya sudah mengalami perbaikan dan peningkatan sehingga menjadi lebih baik.

d) Hasil belajar siswa pada siklus II mencapai ketuntasan.

Pada siklus II guru telah menerapkan model pembelajaran dengan baik dan dilihat dari aktivitas siswa serta hasil belajar siswa pelaksanaan proses belajar mengajar sudah berjalan dengan baik. Maka tidak diperlukan revisi terlalu banyak, tetapi yang perlu diperhatikan untuk tindakan 
selanjutnya adalah memaksimalkan dan mepertahankan apa yang telah ada dengan tujuan agar pada pelaksanaan proses belajar mengajar selanjutnya penerapan model pembelajaran pemberian tugas latihan push up dapat meningkatkan kemampuan standing shoot proses belajar mengajar sehingga tujuan pembelajaran dapat tercapai.

\section{Kesimpulan}

Dari hasil kegiatan pembelajaran yang telah dilakukan selama tiga siklus, dan berdasarkan seluruh pembahasan serta analisis yang telah dilakukan dapat disimpulkan sebagai berikut:

1. Pembelajaran permainan basket dengan teknik melatih push up memiliki dampak positif dalam meningkatkan prestasi belajar dalam hal standing shoot siswa yang ditandai dengan peningkatan ketuntasan belajar siswa dalam setiap siklus, yaitu prasiklus (43,47\%), siklus I 69,59\%), siklus II (91,30\%).

2. Penerapan model pembelajaran latihan push up mempunyai pengaruh positif, yaitu dapat meningkatkan motivasi belajar siswa yang ditunjukan dengan hasil wawancara dengan sebagian siswa, rata-rata jawaban siswa menyatakan bahwa siswa tertarik dan berminat dengan model pembelajaran model sehingga mereka menjadi termotivasi untuk belajar.

\section{Daftar Pustaka}

Ahmadi. (2007). Permainan Bolabasket. Surakarta: Era Intermedia.

Arikunto, S.. (2008). Penelitian Tindakan Kelas, PT. Bumi Aksara, Jakarta.

Bompa, T. O. (1994). Theory and Methodology of Training. Toronto: Kendall/ Hunt Publishing Company.

Kasbolah, Kasihani. (2001). Penelitian Tindakan Kelas (PTK). Malang: Depdikbud.

Muhajir. (2003). Pendidikan Jasmani Teori dan Praktek untuk SMA Kelas X. Jakarta: Penerbit Erlangga.

Irianto. (2002). Dasar Kepelatihan. Yogyakarta: FIK UNY. Fakultas Ilmu Keolahragaan. Universitas Negeri Yogyakarta.

Pridani, Insanistyo, \& Arwin. (2017). Meningkatkan Keterampilan Lay Up Permainan Bola Basket Dengan Penerapan Metode Pembelajaran Kooperatif Tipe Student Team Achievments Divisions (STAD) Siswa Kelas X MIPA SMA Negeri 1 Bengkulu Tengah. Kinestetik : Jurnal Ilmiah Pendidikan Jasmani, 1 (1). 28-34.

RUstanto. (2017). Meningkatkan Pembelajaran Shooting Bola Basket Dengan Menggunakan Media Gambar. Jurnal Pendidikan Olahraga, Vol. 6 (2). Hal 75-86.

Sanjaya, W. (2011). Penelitian Tindakan Kelas. Jakarta: Kencana Prenada. Media Grup.

Sujati. (2000). Penelitian Tindaka Kelas. Yogyakarta. FIP. UNY 
Sukadiyanto. (2011). Pengantar Teori dan Metodologi Melatih Fisik. Yogyakarta: FIK UNY.

Wissel Hall, PH.(2000). Basketball Steps to Succes (Bagus Pribadi. Terjemahan). Jakarta: PT RajaGrafindo Persada. 